\title{
Ferric iron contents of clinopyroxene from cratonic mantle and partitioning behaviour with garnet
}

\author{
A.B. Woodland \\ Institut für Geowissenschaften, Universität Frankfurt, Altenhöferallee 1, 60438 Frankfurt, Germany \\ woodland@em.uni-frankfurt.de
}

Ferric iron is an important minor constituent in most mantle minerals, except for olivine. The interplay between $\mathrm{Fe}^{3+}$ and $\mathrm{Fe}^{2+}$ is controlled by several factors, including oxygen fugacity $\left(f \mathrm{O}_{2}\right)$, crystal chemistry and bulk rock composition. The $f \mathrm{O}_{2}$ is known to vary laterally as well as with depth in the cratonic mantle and this variable has a direct impact on diamond stability (e.g. Woodland \& Peltonen 1999; Woodland \& Koch 2003, McCammon \& Kopylova 2004). Along with garnet or spinel, clinopyroxene $(\mathrm{cpx})$ is known to be an important carrier of $\mathrm{Fe}^{3+}$ in peridotites (Canil \& O'Neill 1996; Woodland et al. 2006). Therefore, it is important to understand the behaviour of $\mathrm{Fe}^{3+}$ in cpx under mantle conditions. In addition, the partitioning systematics of $\mathrm{Fe}^{3+}$ between cpx and either garnet or spinel could have an influence on the interpretation of observed variations in redox state. In this contribution, I focus on the behaviour of $\mathrm{Fe}^{3+}$ in cpx from garnet peridotites.

Ferric iron contents in cpx have been measured by Mössbauer spectroscopy from a suite of garnet peridotite xenoliths from several localities in northern Lesotho (Letseng-la-Tarae, Liqhobong, Matsoku) and South Africa (Kimberley, Jagersfontein, Frank Smith Mine, Finsch). Measurements were made on hand-picked optically clean separates from samples for which $\mathrm{fO}_{2}$ values have been previously reported (Woodland \& Koch 2003). Combining these results with data from Canil \& O'Neill (1996) and Woodland \& Peltonen (1999) yields a data set of over 50 garnet peridotite xenoliths from cratonic mantle beneath southern Africa and Finland. This enlarged data set allows a more robust analysis of the systematics of $\mathrm{Fe}^{3+}$ incorporation in cpx and $\mathrm{Fe}^{3+}$-partitioning behaviour between cpx and garnet than that previously attempted (Canil \& O'Neill 1996).

Measured $\mathrm{Fe}^{3+} / \mathrm{Fe}_{\text {tot }}$ in cpx ranges from $0.10-$ 0.41 and overlaps with values found in cpx from spinel peridotites (e.g. Woodland et al. 2006). Values are elevated in samples that contain coarse phlogopite, consistent with metasomatism leading to addition of $\mathrm{Fe}^{3+}$. A correlation between $\mathrm{Na}$ and $\mathrm{Fe}^{3+}$ is apparent, emphasising the importance of the aegerine, or $\mathrm{NaFe}^{3+} \mathrm{Si}_{2} \mathrm{O}_{6}$ component in these cpxs (Fig. 1a; use of $\mathrm{Na}-\mathrm{Cr}$ accounts for the presence of a $\mathrm{NaCrSi}_{2} \mathrm{O}_{6}$ component that competes for $\mathrm{Na}$ ). Such a relationship is not observed for cpx in spinel peridotites (Fig. 1b, Woodland et al. 2006; Canil \& O'Neill 1995). In these rocks a number of competing substitution mechanisms appear to be operating in cpx, involving not only the $\mathrm{NaFe}^{3+} \mathrm{Si}_{2} \mathrm{O}_{6}$ component, but also a $\mathrm{CaFe}^{3+} \mathrm{AlSiO}_{6}$ component and potentially others (Woodland et al. 2006). In garnet peridotites, the $\mathrm{Al}$ content of cpx is
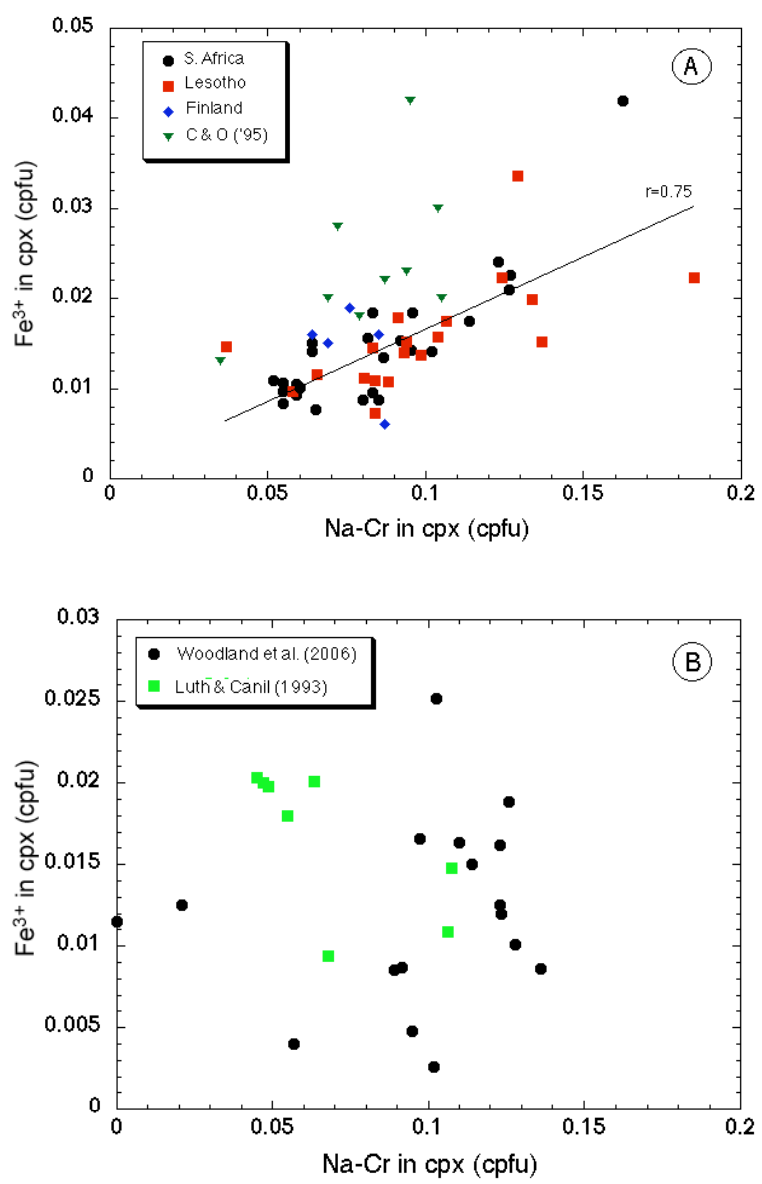

Figure. $1 \mathrm{Fe}^{3+}$ content of clinopyroxene plotted as a function of $\mathrm{Na}-\mathrm{Cr}$ (both as cations per formula unit) for a) garnet peridotites, and b) spinel peridotites. The regression line in a) is for samples from this study from South Africa and Lesotho. 
buffered to generally lower values by the coexistence of garnet with the result that the $\mathrm{NaFe}^{3+} \mathrm{Si}_{2} \mathrm{O}_{6}$ component becomes the dominant mechanism for incorporating $\mathrm{Fe}^{3+}$. Thus, passing from the spinel to the garnet peridotite facies causes a change in how $\mathrm{Fe}^{3+}$ substitutes in cpx.

Thermobarometry

The sample set covers a range in temperatures and pressures indicating that the individual samples originated from depth interval of $\sim 120-220 \mathrm{~km}$ (e.g. see Woodland \& Koch 2003; Canil \& O'Neill 1995). For the majority of samples, temperatures computed using the two-pyroxene thermometer of Brey \& Kohler (1990), [BKN], the garnet-cpx Mg-Fe exchange thermometer of Krogh (1988) and the garnet-olivine $\mathrm{Mg}-\mathrm{Fe}$ exchange thermometer of O'Neill \& Wood (1979) all agree within $\pm 80^{\circ}$, implying that the peridotite assemblage is well equilibrated. In a few cases, one of either the garnet-olivine thermometer or the garnet-cpx thermometer gave inconsistent results with BKN, but never both (e.g. Fig. 2). The reason for these deviations remains unclear. However, the role of $\mathrm{Fe}^{3+}$ can be excluded as there is no correlation between $\mathrm{Fe}^{3+}$ content in garnet or cpx and the degree of deviation from the BKN temperatures.

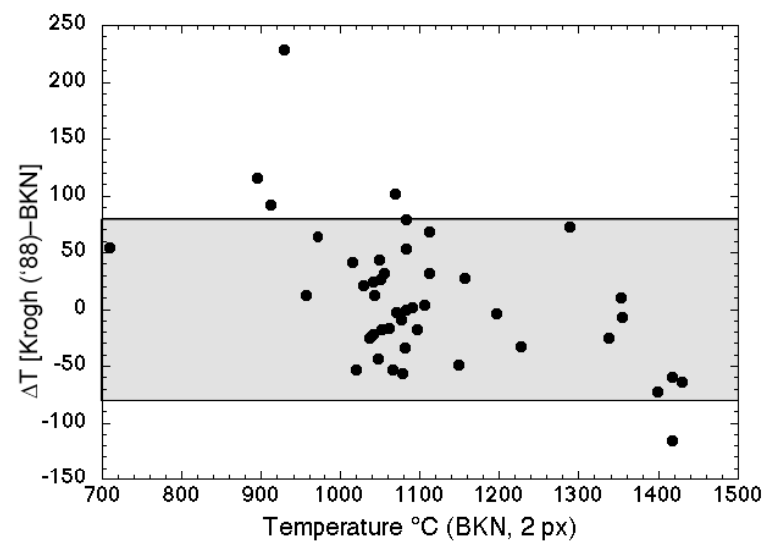

Figure 2. Comparison of temperatures calculated from the two-pyroxene thermometer of Brey \& Köhler (1990) $[\mathrm{BKN}]$ and the garnet-cpx thermometer of Krogh (1988). Agreement within $\pm 80^{\circ}$ is apparent for most samples (grey region).

Temperature and $\mathrm{Fe}^{3+}$ content

Although there is a poor negative correlation between $\mathrm{Fe}^{3+} / \sum \mathrm{Fe}$ in cpx and increasing temperature, no such overall relationship is observed for $\mathrm{Fe}^{3+}$ contents as cations per formula unit (Fig. 3). This lack of correlation can be understood in terms of two factors: 1) $\mathrm{Fe}^{3+}$ incorporation is controlled by a number of factors, including $\mathrm{fO}_{2}$, the degree of depletion of a given sample, as well as the composition of the cpx itself (i.e. Na content as shown in Fig. 1a); 2) $\mathrm{Fe}^{3+} / \sum \mathrm{Fe}$ in cpx will also be directly influenced by changes in
$\mathrm{Fe}^{2+}$ content, which is known to be temperature dependent in the presence of opx and garnet (e.g. Brey \& Köhler 1990; Krogh 1988). This has the effect of partially decoupling $\mathrm{Fe}^{3+} / \sum \mathrm{Fe}$ values from the actual $\mathrm{Fe}^{3+}$ contents. However, the lack of any obvious relationship between temperature and $\mathrm{Fe}^{3+}$ content does not necessarily imply that temperature has no effect on $\mathrm{Fe}^{3+}$ incorporation in cpx.

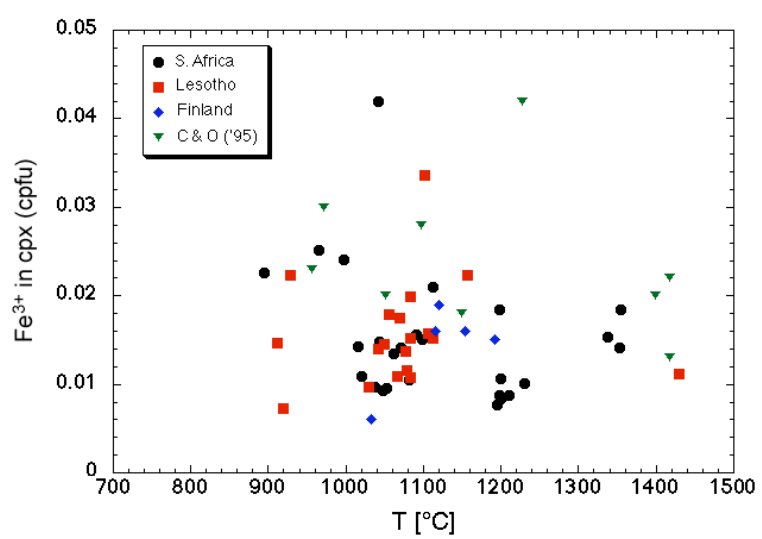

Figure $3 . \mathrm{Fe}^{3+}$ contents as cations per formula unit in cpx plotted against equilibration temperature, as given by the BKN geothermometer.

Partitioning $\mathrm{Fe}^{3+}$ between garnet and cpx

Canil \& O'Neill (1995) considered the partitioning of $\mathrm{Fe}^{3+}$ between garnet and cpx in terms of a simple partition coefficient, $\mathrm{D}^{\mathrm{g} / \mathrm{cpx}}$ and found a significant temperature dependence favouring $\mathrm{Fe}^{3+}$ incorporation in garnet at higher temperatures. Exceptions to this were samples containing spinel or ilmenite, a point also corroborated by Woodland \& Peltonen (1999). Thus, the partitioning systematics of $\mathrm{Fe}^{3+}$ between garnet and cpx can be potentially used as a test of whether spinel is indeed an equilibrium phase in garnet-spinel peridotites.

The derivation of this $\mathrm{D}^{\mathrm{g} t / \mathrm{cp} x}$ was based upon a simplified treatment of the $\mathrm{Fe}^{3+}-\mathrm{Al}$ exchange between aegerine and jadeite components in cpx, and andradite and grossular components in garnet:

$$
\begin{aligned}
& \mathrm{NaFe}^{3+} \mathrm{Si}_{2} \mathrm{O}_{6}+0.5 \mathrm{Ca}_{3} \mathrm{Al}_{2} \mathrm{Si}_{3} \mathrm{O}_{12}= \\
& \text { cpx } \mathrm{gt} \\
& \mathrm{NaAlSi}_{2} \mathrm{O}_{6}+0.5 \mathrm{Ca}_{3} \mathrm{Fe}^{3+}{ }_{2} \mathrm{Si}_{3} \mathrm{O}_{12} \\
& \text { cpx gt }
\end{aligned}
$$

A more rigorous treatment of this exchange equilibrium can be made by considering the thermodynamic activities of these components in the natural garnet and cpx solid solutions. Activities of andradite and grossular were computed from the garnet compositions following the reciprocal solution model outlined by Gudmundsson \& Wood (1995). For cpx, no satisfactory solution model really exists that covers the necessary compositional range containing $\mathrm{Fe}^{3+}$. From Luth and Canil (1993)'s analysis it appears that mixing on sites is a reasonable simplification and this approach was used here. The $\log \mathrm{K}$ for equilibrium 1 is plotted in 
Figure 4 in terms of reciprocal temperature. Also plotted is the $\log \mathrm{K}$ calculated from the Holland \& Powell (1998) data set (version tc330).

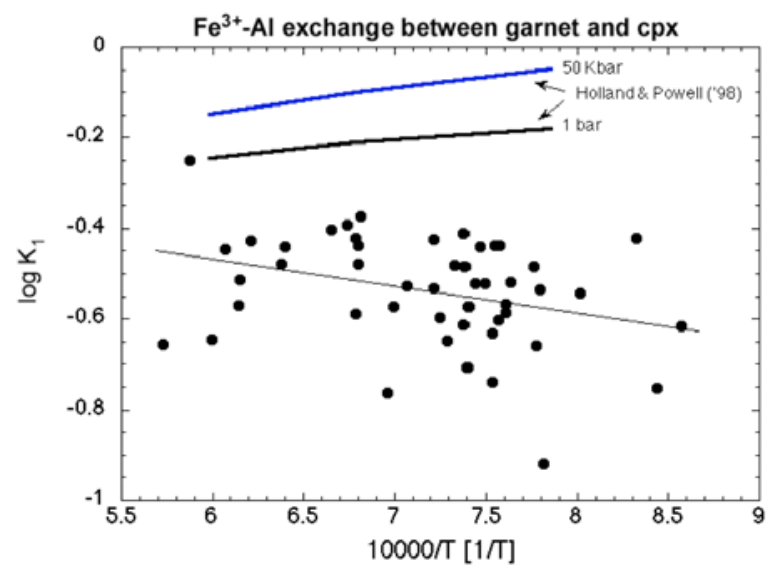

Figure 4. $\log \mathrm{K}$ for the $\mathrm{Fe}^{3+}$ - $\mathrm{Al}$ exchange equilibrium (1) between garnet and cpx plotted as a function of reciprocal temperature. Also shown are the results of calculations for equilibrium 1 using the data of Holland $\&$ Powell (1998). The natural data reveal the tendency for $\mathrm{Fe}^{3+}$ to be incorporated in garnet with increasing temperature (see text).

Although agreement between the calculations presented here and Holland \& Powell (1998)'s is generally pretty good, lying systematically lower by only $0.3-0.5 \log$ units, there is a difference in slope (and temperature dependence) apparent. The scatter in the results from the natural data is no doubt related to the use of the mixing on sites model for the cpx. The effect of pressure on $\log \mathrm{K}$ was ignored in the calculations since $\Delta \mathrm{V}$ of equilibrium 1 is small, on the order of $0.1 \log$ unit as illustrated by the difference in the two curves computed at 1 bar and 50 Kbar using the data of Holland \& Powell (1998). The difference in slope between the natural data and Holland \& Powell (1998)'s data set is likely due to a problem in the tabulated thermodynamic properties of one of the endmember compontents involved in equilibrium 1 . Considering the number of experimental studies on these different compositions, aegerine (acmite) is the likely source of this error.

This treatment of the partitioning of $\mathrm{Fe}^{3+}$ between cpx and garnet reveals that this temperature dependence is much smaller than initially thought. Thus the increase in $\mathrm{Fe}^{3+}$ content of garnet with increasing temperature (also depth) observed by Canil \& O'Neill (1995) and Woodland \& Koch (2003) cannot be only attributed to a redistribution of $\mathrm{Fe}^{3+}$ from cpx. Some changes in bulk composition must also be entertained. Unfortunately, this analysis still suffers from lack of a good mixing model for complex mantle cpx, and especially from uncertainties in the thermodynamic properties of the aegerine endmember.

\section{References}

Brey, G.P., Köhler, T. (1990) Geothermobarometry in four-phase lherzolites II. New thermobarometers, and practical assessment of existing thermobarometers. J Petrol, 31, 1353-1378.

Canil, D., O'Neill, H.St.C. (1996) Distribution of ferric iron in some upper-mantle assemblages. J Petrol, $37,609-635$.

Gundmundsson, G., Wood, B.J. (1995) Experimental tests of garnet peridotite oxygen barometry. Contrib Mineral Petrol. 119, 56-67.

Holland, T.J.B., Powell, R. (1998) An internally consistent thermodynamic dataset for phases of petrological interest. J Metamorph Geol, 16 , 309343.

Krogh E.J. 1988, The garnet-clinopyroxene Fe-Mggeothermometer - a reinterpretation of existing experimetnal data. Contrib. Mineral. Petrol. 99, pp. 44-8.

Luth R.W. \& Canil D. 1993. Ferric iron in mantlederived pyroxenes and a new oxybarometer for the mantle. Contrib. Mineral. Petrol. 113, pp. 236-248.

McCammon C. and Kopylova M.G. (2004) A redox profile of the Slave mantle and oxygen fugacity control in the cratonic mantle. Contrib Mineral Petrol 148 55-68.

O'Neill H St C \& Wood BJ (1979) An experimetnal study of Fe-Mg partitioning between garnet and olivine and its calibration as a geothermometer. Contrib Mineral Petrol, 70, 59-70.

Woodland, A.B. Koch, M. (2003) Variation in oxygen fugacity with depth in the upper mantle beneath the Kaapvaal Craton, southern Africa. Earth Planet Sci Lett, 214, 295-310.

Woodland, A.B., Kornprobst, J., Tabit, A. (2006) Ferric iron in orogenic lherzolite massifs and controls of oxygen fugacity in the upper mantle. Lithos, 89 , 222-241.

Woodland, A.B., Peltonen, P. (1999) Ferric iron contents of garnet and clinopyroxene and estimated oxygen fugacities of peridotite xenoliths from the Eastern Finland Kimberlite Province. P.H. Nixon Volume Proc. 7th Kimberlite Conf, Redroof Publishers, Cape Town, S.A., 904-911. 
